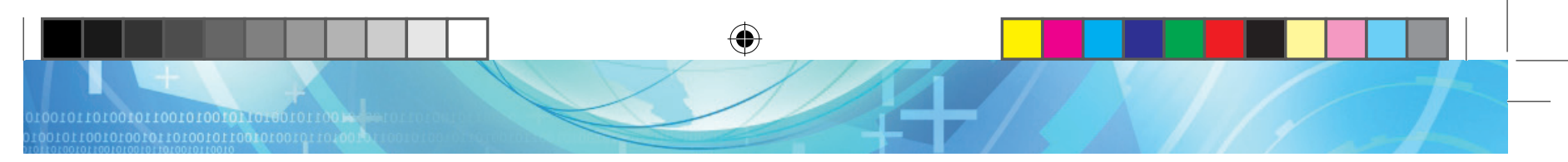

\title{
Household Income and Relationships with Different Power Entities as Determinants of Corruption
}

\author{
Asif Reza Anik', Siegfried Bauer ${ }^{2}$
}

ABSTRACT

This article adds to the corruption literature by identifying factors influencing Bangladeshi farm households' probability of experiencing corruption in different service sectors. The econometric results show that households' probability of being exposed to corruption can largely be explained through their income and their relationship with different power entities. The direction of the relationship between income and corruption vary across services. Relatively rich households have a higher probability of experiencing corruption in sectors such as education, health and electricity. These households are less likely to experience corruption in local government and agricultural extension services. The results here are contrary to the common trend in corruption research that addresses households' aggregate corruption experiences. Households with relationships with different power entities have a lower probability of experiencing corruption than their counterparts without these types of relationships.

KEY WORDS: $\quad$ corruption; income; relationship with power entity; probit model; Bangladeshi farm households

JEL Classification: C3; D1

1'Bangabandhu Sheikh Mujibur Rahman Agricultural University (BSMRAU), Bangladesh

${ }^{2}$ Institute of Farm and Agribusiness Management, Justus-Liebig-Universität Giessen, Germany

\section{Introduction}

When interacting with different public service entities, some households experience corruption and some do not. There are also differences in the forms of corruption experienced by households. Such differences under the same policy and institutional setup can possibly be explained through different household

-

Correspondence concerning this article should be addressed to: Asif Reza Anik, Department of Agricultural Economics Bangabandhu Sheikh Mujibur Rahman Agricultural University (BSMRAU) Salna Gazipur 1706 Bangladesh. Tel.: +88 01764474416. Email:anikbd1979@gmail.com 
dummy variable to identify corruption determinants. Mocan (2008) used the International Crime Victim Survey (ICVS), in which individuals were asked to identify their bribery experiences with government officials without specifying any sector or service. Though the literature provides important insights about microlevel corruption determinants, this aggregation might be misleading. Because demand for services varies across households based on differences in socio-economic characteristics, assuming that a specific type of household is equally vulnerable to corruption in all sectors may be inappropriate. Furthermore, household level characteristics may influence households' probability of experiencing a particular form of corruption (Anik et al., 2013), and a particular service may be more prone to a specific form of corruption.

In the literature, the most pronounced determinant of corruption is a household's economic status, generally measured by income. Rich people have a higher probability of experiencing corruption, specifically bribery (Hunt, 2004; Mocan, 2008; Torgler \& Valev, 2006). The rich have higher demand and hence higher interactions with service entities, which increases their probability of exposure to corruption. To a corrupt official, wealthy households are a better potential source for extracting bribes than those with less wealth. Furthermore, as the rich have relatively less marginal cost for a bribe of the same amount than the poor, they might be assumed to be less reluctant to enjoy services through bribery. However, an alternative hypothesis can be offered here. Demand for services such as relief, social safety net programs, etc. decreases with an increasing income level and people belonging to lower-income deciles may become more vulnerable to corruption. Such possibilities are still not explored in the literature. We expect to observe different types of impact from income on corruption by disaggregating among different services.

Svensson (2003) identified three common features in the available corruption literature. These features are (1) cross-country analyses, (2) based on perception indices, and (3) foreign experts' assessments of the overall corruption in a country. The literature explains corruption as an outcome of countries' policyinstitutional environment. He also mentioned that due to the use of aggregated data, these cross-country analyses can hardly explain within country variations.
Moreover, concerns about perception biases can lead to doubts about the acceptability of these studies. The corruption literature is primarily concerned with the impact of corruption on different macro-level economic or development indicators, primarily due to the unavailability of micro-data versus the relatively easy access to aggregate-level corruption data (Mocan, 2008). Due to the secretive nature of corruption, in most cases it is difficult to find direct witnesses of corruption, especially when it creates a win-win situation (Johnston, 2000).

In this article, we try to address some of these limitations in the existing literature. Instead of perception data, we analyze households' own corruption experiences in different sectors. We argue that as households exhibit differences in corruption experiences under the same policy-institutional set-up, such differences can be explained through different household and community level characteristics. We analyze households' experiences across services to identify sector-wise determinants of corruption. While doing so, we show that the trend in the corruption literature to aggregate households' corruption experiences can be misleading.

The entire paper is divided into five sections. This introductory section is followed by the literature review section. The third section contains the data and the analytical procedure, and describes the sampling techniques, data and econometric models. The next section offers the results and discussion, and the findings of the study are presented and discussed. Finally, the results are summarized in the conclusion.

\section{Literature Review}

Kowalewski (2012) argued for the importance of internal governance factors along with external regulations in pension fund performance in Poland. He observed differences in pension fund performances under homogeneous external regulations. Such differences were explained through internal institutional factors such as different characteristics of the board members and chairmen, but the socio-economic characteristics of the pension receivers were not addressed.

Swamy et al. (2001) used both micro and macro level datasets to explore the relationship between corruption and gender. Their analyses using micro data show that women are less involved in bribery than men and less likely to admit that bribery activities are justifiable. 


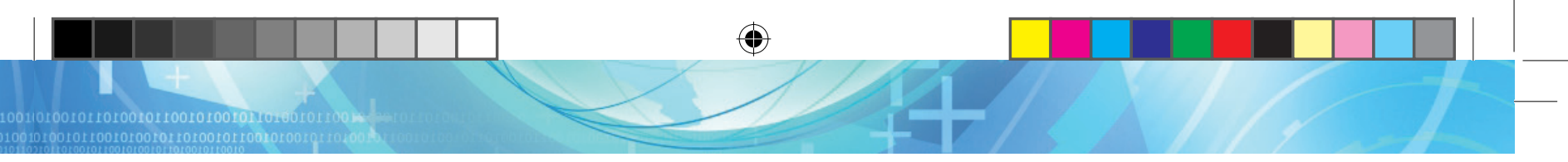

In cross-country analysis, they found that corruption is less severe in countries in which women make a relatively higher contribution in parliament, senior bureaucratic positions and the labor force. Similar findings are noted in the works of Alatas et al. (2006), Mocan and Rees (2005), Mocan (2008), Torgler and Valev (2006). Mocan's (2008) analysis using data from 49 countries also showed that high income individuals, people living in large cities and those with more education have a higher probability of being exposed to corruption. He also mentioned several country level characteristics that influence corruption probabilities. These include a country's unemployment rate, average education, and the strength of its institutions.

Through ordered probit models, Torgler and Valev (2006) investigated the determinants of differences in the justifiability of corruption in eight Western European countries. Exploring the relationship between age and corruption was these researchers' primary interest. They found strong age effect (the changing attitudes of the same cohort over time), but no cohort effect (differences in attitudes among similar age groups in different time periods). Due to the higher degree of social norms, more educated and married people have lower justifiability of bribery. Among different economic classes, the highest economic class has the lowest justifiability of corruption. As the marginal utility loss (wealth reduction) when caught and penalized for corruption is lower for individuals with a higher income, these individuals are more likely to accept bribery. Herrera et al. (2007) also found the incidence of petty corruption more common among richer households in Peru. They estimated that bribery as a share of food expenditure is higher for households belonging to the upper economic classes.

Dividing the sample into different income groups, Hunt (2004) found that the intensity of bribery is higher for the rich compared to the poor. For the two middle-income groups, no clear relationship between bribery and income is observed. She observed city size, gender, age and ownership of a car to have larger effect on bribery than income. Trust networks that enable an individual to find substitutes for bribery through nonmonetary payment are mentioned as an important factor behind such variation. In another study, Anik et al. (2013) observed that a relationship with power entities reduces households' probability of experienc- ing corruption in its different forms. Relationships also significantly reduce the bribe amount.

Hunt and Laszlo (2005) developed a theoretical framework and found that income and incidence of bribery increase simultaneously, as does the bribe amount. Their work provided empirical evidence that refusing to bribe increases a household's probability of being excluded from the service. In the case of Ugandan firms, Svensson (2003) found a positive correlation between firm profit and bribe amount.

Čábelková and Hanousek (2004) explored the role of perception as a determinant of corruption by analyzing 2600 Ukrainian respondents' opinions. Among different professional groups, they found businessmen and peasants to be more willing to engage in bribery. As businessmen are more likely to extract a benefit from bribery than others, their willingness to bribe is also higher. To justify Ukrainian peasants' higher willingness to bribe, they referred to Harrison (1985). Peasants tend to believe that things that exist in this world are finite/limited in quantities, similar to their farm area and land productivity. Hence, they believe less in their own capability and in effort as a source for betterment. For peasants, grabbing a bigger piece of the social pie is the easiest and most comprehensible path to betterment. Bribing dishonest government officials to obtain a higher share of the social pie is therefore a more practiced option. The study also emphasized the media's role in controlling corruption by creating perceptions. If media broadcast that there is a higher level of corruption than actual, some citizens may gain the impression that bribery is required in government offices. Ultimately, some people might be encouraged to bribe.

\section{Data and Empirical Model}

Sampling Techniques and Data: The empirical analysis is based on information collected from 210 Bangladeshi farm households belonging to six villages in six different districts of the country. Among these households, $99.1 \%$ received service from at least one sector during July 08-June 09. The highest proportion of households received service from the education sector $(78.6 \%)$. The education sector is followed by health (66.2\%), electricity (48.6\%), agricultural extension $(42.1 \%)$ and local government $(41.0 \%)$ in terms of number of service recipients (Table 1). A multi-stage 
sampling technique was applied to select the respondent households. The first three stages were for selecting the survey areas (e.g., selection of districts, upazila ${ }^{1}$ and villages), whereas respondent farmers were selected at the final stage. At the first stage, all of the districts with above-median rice production ${ }^{2}$ in 2008/09 were selected. Then, we ranked these districts based on the proportion of households experiencing corruption in different service sectors. The ranking was performed using Transparency International Bangladesh's [TIB] database of 'National Household Survey 2007 on Corruption in Bangladesh'. From this ranking, the top three and bottom three districts were chosen. From each district, the upazila with the highest rice production was selected, and from each upazila, the highest rice producing village was selected. ${ }^{3}$ Due to this purposive sampling procedure, our sample, and hence our results, might be biased towards extensive rice producing areas. Finally, the survey interviewed 35 randomly selected rice producing farm households from each village from the list of farmers available with the local extension agents.

Households' own experiences facing corruption during July 08 -June 09 were collected through a semistructured interview schedule. The survey was conducted during September 09 and October 09. The survey collected detailed information about households corruption and farming experiences. This article analyzes households' corruption experiences with five different service sectors, namely education, health, electricity, local government, and agricultural extension services. Together with information regarding corruption experiences, the households were asked to provide detailed information about their demography and different socio-economic characteristics such as income and expenditure patterns, land holding, education, relationships with different organizations and power entities, etc. The data collected during the survey were self-reported by the households, but assistance was provided by the enumerators to give households a proper understanding of corruption and its different forms such as nepotism/favoritism and negligence of duty. Adequate care was taken so that the enumerators did not influence the households' opinions. In the case of bribery data, instead of asking direct questions about bribe amounts, the households were asked about their paid cost or price for the service. A household was considered to have paid a bribe when the paid price was higher than the announced price.

Furthermore, qualitative approaches such as Focus Group Discussions (FGD) and Key Informant Interviews (KII) were applied to understand and explain the quantitative results. A FGD was conducted in every village, and the farm household heads were the participants. KIIs were conducted with the farmers, extension workers, local government representatives, and educated people of the villages. Interviews were also conducted with academicians, development workers and researchers.

Corruption Experiences of the Sample Households: At least one out of every two households experienced corruption in one of the sectors under consideration (Table 1). The highest proportion of households experienced corruption in the local government. In this sector, three out of every five service recipients faced corruption. The proportion of service recipient households experiencing corruption is similar in other four sectors (Table 2).

Corruption has different faces and forms. Bribery and negligence of duty are the two most common forms of corruption faced by farm households. Among the households that experienced corruption, 35.2\% and $34.9 \%$ reported bribery and negligence of duty, respectively. Incidences of nepotism/favoritism were reported by $18.1 \%$ of the respondents. Other forms of corruption such as extortion, embezzlement, and deception were sporadic. During the survey, $11.8 \%$ of households experiencing corruption reported the existence of these types of corruption (Figure 1). Bribery is also found to be the most dominant form of corruption in TIB's survey, followed by negligence of duty. In TIB, $38.6 \%$ and $38.3 \%$ of the surveyed households experienced bribery and negligence of duty, respectively (TIB, 2008).

Forms of corruption vary across sectors. Bribery is the most dominant form of corruption in electricity (56.0\%), education (52.8\%) and local government (44.8\%). Only in agricultural extension services and the health sector is bribery not the dominant form of corruption. Though it is not the dominant form in the health sector, the incidence of bribery here is notably high (41.7\%). Interestingly, in agricultural extension services, none of the households experienced bribery. As no cost is associated with the extension services, 
Table 1. Proportion of households receiving services and facing corruption in different sectors

\begin{tabular}{ccc}
\hline Name of the sector & \% of HHs receiving services $(\mathbf{n = 2 1 0 )}$ & $\begin{array}{c}\text { \% of service recipients facing } \\
\text { corruption }\end{array}$ \\
\hline Education & 78.6 & 20.6 \\
Health & 66.2 & 15.1 \\
Electricity & 48.6 & 24.5 \\
Local government & 41.0 & 60.5 \\
Agricultural extension & 42.4 & 17.9 \\
All sectors & 99.1 & 52.4 \\
\hline
\end{tabular}

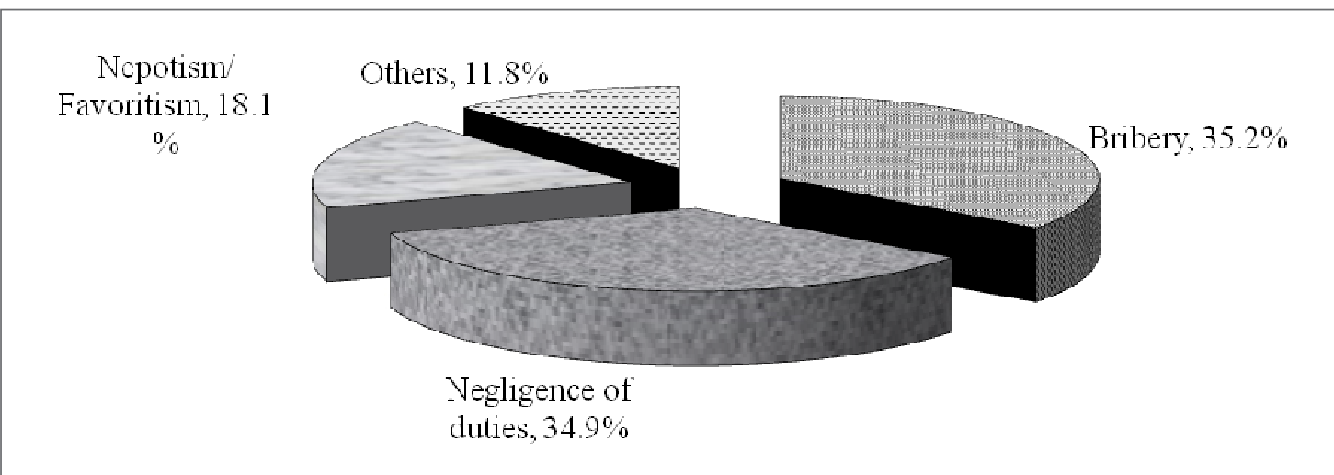

Figure 1. Different forms of corruption experienced by households (\% of households experiencing corruption)

Table 2. Proportion of households experiencing different forms of corruption in different sectors (\% of households who experienced corruption)

\begin{tabular}{ccccc}
\hline \multicolumn{5}{c}{ Forms of corruption } \\
\hline Sectors or services & Bribery & Negligence of duty & Nepotism / Favorites & Others \\
Education & 52.8 & 27.8 & 16.7 & 2.8 \\
Electricity & 56.0 & 40.0 & 0.0 & 4.0 \\
Health & 41.7 & 50.0 & 4.2 & 4.2 \\
Local government & 44.8 & 13.8 & 22.4 & 19.0 \\
Agricultural extension & 0.0 & 52.9 & 29.4 & 17.6 \\
\hline
\end{tabular}

the scope for financial transactions in the office is limited, which likely restricted the extension workers from extracting bribes from households. During the FGD, farmers rarely expressed any positive ideas or impressions about the effectiveness and quality of the extension services and rarely believed that these services were helpful to their farming practices. Most likely, the farmers did not find these services worthy of access through bribery. Negligence of duty is the most dominant form of corruption in agricultural extension services (52.9\%) and the health sector (50.0\%). In the extension services, negligence of duty is followed 
by nepotism/favoritism (29.4\%). Incidences of other forms of corruption, which include embezzlement and extortion, are also comparatively higher in the extension services (17.6\%) (Table 2). Specifically speaking, while organizing demonstration plots, farmers receive less than the allotted quantity of inputs. Similarly, trainees receive less training allowance in training programs. The corrupt extension officials steal the inputs and allowances.

Analytical Model: The earlier discussion shows that notable differences exist in households' corruption experiences across sectors, e.g., a household experiencing corruption in one sector may or may not experience corruption in other sectors. Forms of corruption also vary across sectors. We try to address these differences through some individual and community level factors.

To analyze households' corruption experience (did the household face corruption in that sector during the referenced period or not) in binary terms, we use the probit model approach. For each sector or service, a probit model is developed. As the number of service recipients varies across sectors, so does the number of observations across models. A household's corruption experience in a sector is the dependent variable in the model developed for that specific sector. A probit model is the most commonly used econometric tool in the microeconomic literature exploring corruption determinants (e.g., Alatas et al., 2006; Č́aelková \& Hanousek, 2004; Hunt, 2004; Hunt \& Laszlo, 2005; Shaw, 2009; Swamy et al., 2001; Torgler \& Valev, 2006). The explicit form of the probit model used in our study is as follows:

$$
\begin{aligned}
& \operatorname{Pr}\left(y_{i}=1 \mid \begin{array}{l}
\text { location }_{i}, \text { edu }_{i}, \text { enroll }_{i}, \ln \text { income }_{i}, \\
\text { land }_{i}, d r_{i}, \text { rpr }_{i}, \text { go }_{i}, d_{i}
\end{array}\right) \\
& =\Phi\left(\begin{array}{l}
\beta_{1} \text { location }_{i}+\beta_{2} \text { edu }_{i}+\beta_{3} \text { enroll }_{i}+\beta_{4} \ln \text { income }_{i} \\
+\beta_{5} \text { land }_{i}+\beta_{6} d_{i}+\beta_{7} \text { rpr }_{i}+\beta_{8} \text { go }_{i}+\beta_{9} d_{i}+\varepsilon_{i}
\end{array}\right)
\end{aligned}
$$

where $\operatorname{Pr}$ is the probability; $y_{i}$ is the $i$ th household's corruption experience, binary in nature and varying across models; $\Phi$ is the cumulative distribution function $(\mathrm{CDF})$ of the standard normal distribution location $_{i}$ is the dummy of location ( 1 = peri-urban, 0 = rural); $e d u_{i}$ is the education of the household head (years); enroll $_{i}$ is the number of member(s) enrolled in different educational institutions; $\ln$ income $_{i}$ is the log of the household's per-capita annual income (BDT/ person); land $_{i}$ is the per-capita land ownership (ha/ person); $d r_{i}$ is the dependency ratio; $r p r_{i}$ is the dummy for the household's relationship with public representatives ( 1 =have relationship); $g o_{i}$ is the dummy for the household's relationship with government offices (1=have relationship); and $d_{i}$ is the dummy for the sector specific relationship variable (1=have relationship). The four sector-specific relationship variables used are relationship with educational institutions in the model for educational institutions; relationship with medical professionals in the health sector model; relationship with local administration in the model for local government; and relationship with extension office in the model for extension services. A household was identified as having a relationship with an institution or organization only after satisfying two conditions: first, the household has a family member(s) and/or relative(s) and/or friend(s) as an elected public representative at the national or local level and/or working in government offices (office of the sub-district executive officer, law enforcement agencies, and the judiciary office) and/or in institutions or organizations from which the household was seeking service; and second, when the household makes requests to the aforementioned person, he/she feels an obligation to carry out the request and has the ability to do so. The relationship here that makes the official work for the household may be both personal and business. Table 3 elaborately explains the measurement techniques for the explanatory variables. The parameters $\beta_{1}, \ldots, \beta_{k}$ are typically estimated via the maximum likelihood estimation (MLE) procedure. All of the models were checked for heteroskedasticity by running a heteroskedastic probit model. The likelihoodratio tests for the models suggest that none of the models has a heteroskedasticity problem.

Endogeneity Problems: The local government provides some services such as allowances or creating employment opportunities. Corruption may play a role in households' access to these services and affect households' income. Hence, there might be simultaneous causality between income and corruption in local government. To address the endogeneity arising from simultaneous causality, we use a two stage least squares (2SLS) estimation technique, which is the most common among the different instrumental variable (IV) methods (Bascle, 2008; Hahn, Hausman, \& Kuersteiner, 2004; Murray, 2006). Four variables are introduced as 


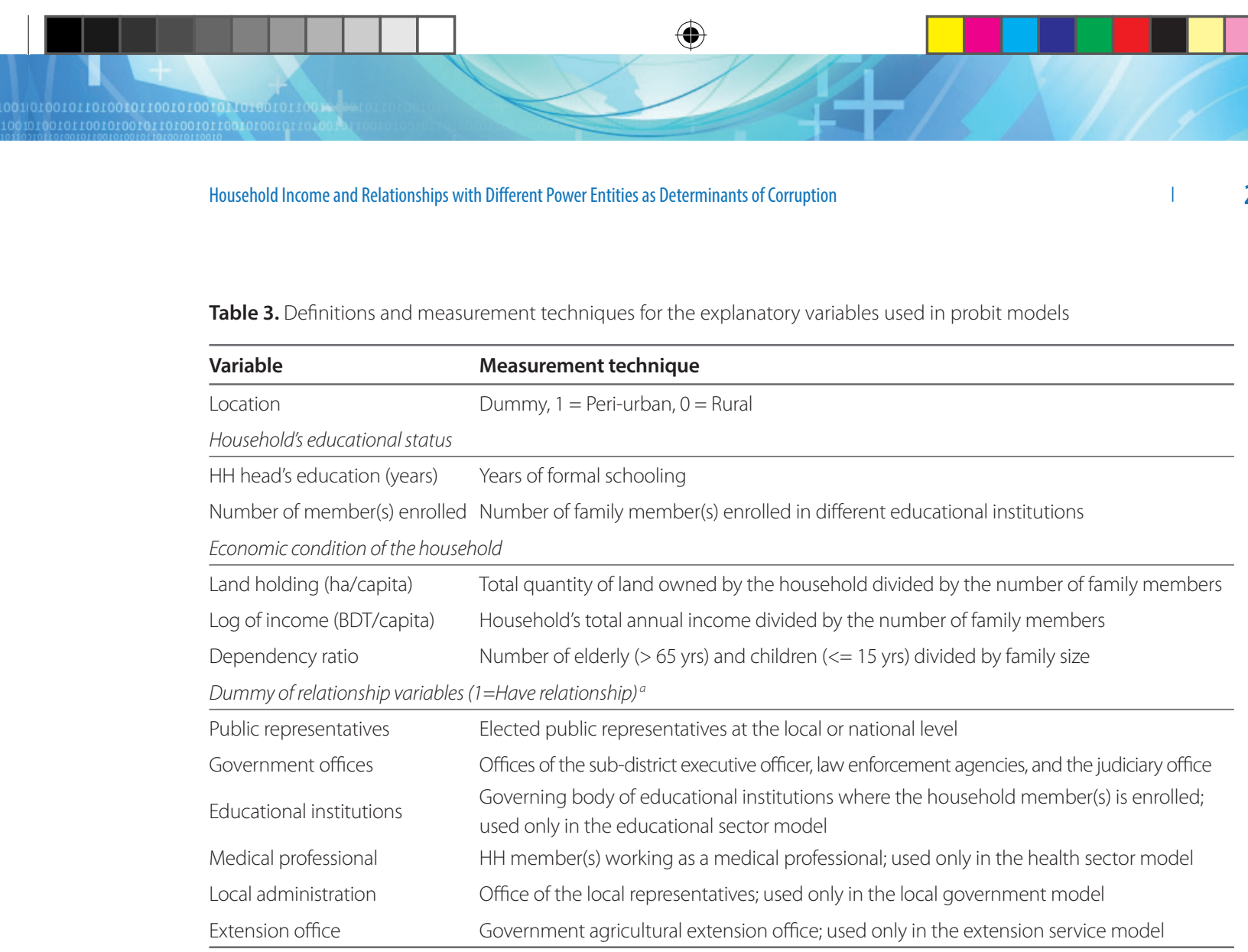

Note: ${ }^{\text {a }}$ A household is identified as having a relationship only after satisfying the following conditions:

- The household has family member(s) and/or relative(s) and/or friend(s) as public representatives or working in the institution(s) or organization(s); these persons hold some influence over the service delivery entities.

- When households make requests to the aforementioned persons, these persons will feel obligated to carry out the request and have the ability to carry it out.

instruments: land holdings (ha/person), age of the household head (years), number of family members and dummy for access to off-farm income activities (1=households with access).

One of the crucial parts of an IV analysis is confidence about theoretical consistency through several statistical tests. Three tests, namely the Amemiya-LeeNewey overidentification test, the Smith-Blundell test, and the Wald test of exogeneity, were therefore conducted. The test results are available in Table 4. Based on these test results, we can conclude that though we have correctly chosen the instruments, the income variable is not endogenous. Hence, instead of an ivprobit model, we develop a probit model for the local government. ${ }^{4}$

One may also suspect endogeneity problems between a household's corruption experiences and different relationship variables. Past experiences with corruption and/or a future expectation of facing cor- ruption may encourage a household to develop relationships with power entities. In our models, we consider a household to have a relationship with a power entity only when the household claimed to have their 'members and/or close relatives and/or friends' within the power entity. Even after having such a person in a power entity, a household was not treated as having a relationship unless the household claimed that its request of the power entity was somewhat obligatory. A relationship that induces obligation cannot be developed in a short period of time. When a household faces or expects to face corruption, it may try to develop a relationship with the power entity. However, such a relationship may not imply any obligation by the power entity. The power entity may or may not feel the need to do something for the household. In our case, by mentioning the word 'obligatory' as a criterion to identify 'close relatives and/or friends', we limited the scope of inclusion for any short-term relationship. 
Table 4. Testing endogeneity for the income variable in the local government model

\begin{tabular}{lc}
\hline Tests & $\chi^{2}$ value (p-value) \\
\hline Amemiya-Lee-Newey overidentification test & $1.73(0.42)$ \\
Wald test of exogeneity & $0.71(0.40)$ \\
Smith-Blundell test of exogeneity & $0.30(0.58)$ \\
\hline
\end{tabular}

It may not always be possible for a household to try to develop relationships with a power entity when it faces corruption in the service sector, mostly due to time constraints. A household must decide whether or not to pay bribes while waiting in the service queue. It is less likely that a household returns from the queue and tries to develop a relationship with the power entity; e.g., while admitting a member to the hospital, if a household is asked for a bribe, it is hard to believe that instead of paying the bribe, the household will return from the hospital and try to develop a relationship with a power entity to avoid bribery. Hence, we believe there are enough grounds to ignore simultaneous causality between relationship variables and households' corruption experiences. However, in the longer term, simultaneous causality might be an issue. Because we have cross-sectional data, it is beyond the scope of this study to analyze such possibilities. This might be a new arena for future research.

\section{Results and Discussions}

Descriptive Statistics of the Explanatory Variables Used in the Econometric Models: The average annual income of the sample households is $49001 \mathrm{BDT} /$ person. One out of every three households is from a periurban area. The average education of the household head is around primary level. The respondents are mostly small farmers with $0.15 \mathrm{ha} /$ person of land. The estimated dependency ratio of 0.3 implies that ten economically active people between 15 and 64 years of age are expected to support three other inactive individuals within the household, though age may not necessarily indicate whether an individual is economically active or not. Among the sample households, $33 \%$ and $24 \%$ have relationships with public representatives and different government offices. Summary statistics of the sector specific relationship variables show that $11 \%$, $20 \%$ and $31 \%$ of sample households have a relation- ship with the governing body of educational institutions, local administration and extension offices. Six out of every hundred households have family members working as medical professionals (Table 5).

Factors Influencing Households' Probability of Experiencing Corruption: Household level determinants of corruption experiences in different sectors are presented in Table 6 . We tried alternative model specifications incorporating both the linear and the quadratic form of the income variable together with other exogenous variables. Nevertheless, this new specification did not bring any notable change in the results in terms of coefficients' value, sign and level of significance compared to the results presented in Table 6. Moreover, the quadratic term is insignificant in all of the models. However, inclusion of the quadratic term means that the marginal effect of income on corruption is captured by both the linear and the quadratic form of the income variable. To avoid such difficulties and for easy explanation and understanding of the results, we report the models using the linear form of the income variable.

The income variable significantly influences households' corruption probabilities across sectors. The associated signs with the variable in different models imply that with increasing income, households' probability of experiencing corruption in education, health and electricity increases, whereas the opposite occurs in local government and extension services. The estimated marginal effect of the variable implies that a household's probability of experiencing corruption in educational institutions increases by $1.22 \%$ when its per capita annual income increases by $1,000 \mathrm{BDT}$. The same increase in income will result in $0.64 \%$ and $1.03 \%$ increases in the probability of experiencing corruption in the health and electricity sectors, respectively. However, in local government and agricultural extension services, the same increase in income will 
Table 5. Summary statistics of the variables used in the econometric models

\begin{tabular}{lc}
\hline Variables & Mean \\
\hline Income (BDTa/person) & $49001.0(87390.85)$ \\
Land holding (ha/person) & $0.15(0.16)$ \\
Dependency ratio & $0.30(0.20)$ \\
HH head's education (years) & $5(5)$ \\
Number of member(s) enrolled in different educational institutions & $1.42(1.07)$ \\
Proportion of households living in peri-urban areas & $0.33(0.47)$ \\
Proportion of households having relationship with & \\
\hline Public representatives & $0.33(0.47)$ \\
Government offices & $0.24(0.43)$ \\
Educational institutes & $0.11(0.32)$ \\
Medical professional & $0.06(0.23)$ \\
Local administration & $0.20(0.40)$ \\
Extension office & $0.31(0.47)$ \\
\hline
\end{tabular}

Note: Figures in parentheses are standard deviations

axchange rate: 1 BDT $=0.10$ euro approximately during 2008-2009

reduce a household's probability of experiencing corruption by $3.6 \%$ and $1.44 \%$, respectively. Here, it is worth mentioning the findings of Anik et al. (2013), who explored the same database used here. Their effort was to identify the determinants of corruption and its different forms in the service sectors. While doing so, they did not distinguish between households' experiences across services. They found that households with higher expenditures are more likely to experience corruption. We estimated a positive relationship between households' economic status and corruption experiences in health, education and electricity but a negative relationship in the other two sectors. The differences in findings between the two studies are suggestive against the aggregation of households' corruption experiences. While analyzing the determinants of other forms of corruption, Anik et al. (2013) found that the bribe frequency and amount is higher for households with higher expenditures. However, household expenditure is negatively correlated with negligence of duty and nepotism/favoritism. For other variables, the two studies do not show much difference.

The estimated relationship between income and corruption probability in education, health and electricity are consistent with the findings of Hunt (2004),
Herrera et al. (2007), Torgler and Valev (2006) and Mocan (2008). The literature has mentioned several reasons for a rich household's higher probability of being exposed to corruption. These reasons include higher demand for services and hence more interactions with service delivery entities, higher ability to pay bribes, and a relatively lower marginal cost for a bribe of the same amount.

However, these arguments become insufficient when explaining the inverse relationship between income and corruption in local government and extension services. To understand the background reasoning of a negative relationship in local government, one must look at the local government services. Some services are targeted towards people belonging to lower-income deciles, e.g., different social safety net programs; allowances for the elderly, distressed women and low income groups; distribution of government lands, etc. The local government also conducts some trials and arbitration to resolve disputes. The local government can only help in negotiations between two conflicting people or groups; it is not authorized to enforce its decisions or to penalize anybody. Hence, final solutions may not come from the local government. This limitation could encourage rich households 
Table 6. Estimated probit models for determinants of corruption in different sectors

\begin{tabular}{|c|c|c|c|c|c|}
\hline & Education & Health & Electricity & $\begin{array}{c}\text { Local } \\
\text { government }\end{array}$ & Extension \\
\hline Regressors & $\begin{array}{l}\text { Marginal effect } \\
(\text { S.E. })^{\mathrm{a}}\end{array}$ & & & & \\
\hline Income & $\begin{array}{c}0.122 \\
(0.043)^{* * *}\end{array}$ & $\begin{array}{c}0.064 \\
(0.036) *\end{array}$ & $\begin{array}{c}0.103 \\
(0.058)^{*}\end{array}$ & $\begin{array}{c}-0.360 \\
(0.179)^{* *}\end{array}$ & $\begin{array}{c}-0.144 \\
(0.073)^{* *}\end{array}$ \\
\hline Land holding & $\begin{array}{l}-0.056 \\
(0.178)\end{array}$ & $\begin{array}{l}-0.280 \\
(0.263)\end{array}$ & $\begin{array}{l}-0.037 \\
(0.254)\end{array}$ & $\begin{array}{l}-0.227 \\
(1.224)\end{array}$ & $\begin{array}{l}-0.029 \\
(0.407)\end{array}$ \\
\hline Dependency ratio & $\begin{array}{c}0.053 \\
(0.147)\end{array}$ & $\begin{array}{c}0.148 \\
(0.137)\end{array}$ & $\begin{array}{c}0.041 \\
(0.226)\end{array}$ & $\begin{array}{c}0.100 \\
(0.454)\end{array}$ & $\begin{array}{l}-0.311 \\
(0.212)\end{array}$ \\
\hline HH head's education & $\begin{array}{c}-0.013 \\
(0.006)^{* *}\end{array}$ & $\begin{array}{c}-0.013 \\
(0.006)^{* * *}\end{array}$ & $\begin{array}{c}0.003 \\
(0.009)\end{array}$ & $\begin{array}{c}0.036 \\
(0.026)\end{array}$ & $\begin{array}{c}0.008 \\
(0.008)\end{array}$ \\
\hline $\begin{array}{l}\text { Number of members } \\
\text { enrolled }\end{array}$ & $\begin{array}{c}0.044 \\
(0.034)\end{array}$ & $\begin{array}{c}0.029 \\
(0.024)\end{array}$ & $\begin{array}{c}0.034 \\
(0.037)\end{array}$ & $\begin{array}{l}-0.059 \\
(0.082)\end{array}$ & $\begin{array}{l}-0.002 \\
(0.037)\end{array}$ \\
\hline Location & $\begin{array}{c}0.173 \\
(0.075)^{* * *}\end{array}$ & $\begin{array}{l}-0.041 \\
(0.056)\end{array}$ & $\begin{array}{c}0.127 \\
(0.096)\end{array}$ & $\begin{array}{c}0.176 \\
(0.168)\end{array}$ & $\begin{array}{c}0.017 \\
(0.091)\end{array}$ \\
\hline \multicolumn{6}{|c|}{ Relationship variables (1=Have relationship) } \\
\hline Public representatives & $\begin{array}{c}-0.115 \\
(0.056)^{* *}\end{array}$ & $\begin{array}{c}-0.131 \\
(0.051)^{* * *}\end{array}$ & $\begin{array}{c}-0.241 \\
(0.073)^{* * *}\end{array}$ & $\begin{array}{c}-0.391 \\
(0.163)^{* * *}\end{array}$ & $\begin{array}{l}-0.051 \\
(0.086)\end{array}$ \\
\hline Government offices & $\begin{array}{c}-0.193 \\
(0.049) * * *\end{array}$ & $\begin{array}{c}0.013 \\
(0.068)\end{array}$ & $\begin{array}{c}-0.199 \\
(0.079)^{* *}\end{array}$ & $\begin{array}{l}-0.197 \\
(0.254)\end{array}$ & $\begin{array}{l}-0.042 \\
(0.105)\end{array}$ \\
\hline Educational institutions & $\begin{array}{c}-0.147 \\
(0.046)^{* * *}\end{array}$ & & & & \\
\hline Medical professional & & $\begin{array}{l}-0.081 \\
(0.062)\end{array}$ & & & \\
\hline Local administration & & & & $\begin{array}{c}-0.696 \\
(0.115)^{* * *}\end{array}$ & \\
\hline Extension office & & & & & $\begin{array}{c}-0.249 \\
(0.088)^{* * *}\end{array}$ \\
\hline Prob > chi2 & 0.000 & 0.0296 & 0.177 & 0.000 & 0.0228 \\
\hline Log likelihood & 37.62 & 18.52 & 18.51 & 48.86 & 19.29 \\
\hline Number of observations & 164 & 139 & 102 & 86 & 95 \\
\hline
\end{tabular}

Note: ${ }^{*}$,* , and ${ }^{* * *}$ indicate significance at the $10 \%, 5 \%$, and $1 \%$ levels, respectively.

${ }^{a}$ Instead of coefficients, the marginal effects estimated at mean are reported here.

to access judiciary services, but poor households are less likely to do so because of the financial implications. Therefore, the poor are more likely to interact with the local government than the rich and thereby become more vulnerable to corruption. Furthermore, compared to other sectors, local administration must work more closely and intimately with the community. Favoring relatively rich households can be a technique for the local government because the rich can help the local government, for example, by creating and main- taining influence in the locality, controlling unrest, and even in election issues.

Unlike in other sectors, in extension services there was no incidence of bribery. A higher ability to pay bribes increases rich households' probability of facing corruption (Herrera et al., 2007; Mocan, 2008; Torgler \& Valev, 2006). The result here can be more specifically interpreted by focusing on forms of corruption other than bribery. In the extension services sector, negligence of duty was the most dominant form of corrup- 
corruption in sectors such as education, health and electricity. The same variable significantly reduces a household's probability of being exposed to corruption in local government and agricultural extension services. The significant impact of the income variable highlights officials' tendencies to maximize bribes.

Relationships with different power entities reduce a household's probability of being exposed to corruption. This inverse relationship is an outcome of the officials' tendency to avoid conflict with the power entities in anticipation of the implicit form of Hunt's (2004) quid pro quo. Households with educated heads are less likely to experience corruption in education and health services. Peri-urban households have a higher probability of experiencing corruption in educational institutions than rural households.

The results regarding the income variable do not lend unmixed support to the generalized hypothesis that the rich have a higher probability of facing corruption. Rich and poor have different demand levels for goods and services and hence have different probabilities of experiencing corruption. The effects of such differences are observed by differentiating households' experiences among different services. The findings of this article reveal the limitations of the popular trend in corruption research addressing aggregate corruption experiences.

\section{References}

Alatas, V., Cameron, L., Chaudhuri, A., Erkal, N. \& Gangadharan, L. (2006). Gender and Corruption: Insights from an Experimental Analysis (Research Paper No. 974). The University of Melbourne. Department of Economics.

Anik, A. R., Bauer, S. \& Alam, M. J. (2013). Why farm households have differences in corruption experiences? Evidences from Bangladesh. Agricultural Economics, 59 (10), 478-488.

Bascle, G. (2008) Controlling for Endogeneity with Instrumental Variables in Strategic Management Research. Strategic Organization, 6 (3), 285-327.

Bangladesh Rice Research Institute (2012). Rice in Bangladesh. Retrieved from http://www.knowledgebank-brri.org/riceinban.php

Čábelková, I., \& Hanousek, J. (2004). The power of negative thinking: Corruption perception and willingness to bribe in Ukraine. Applied Economics, 36 (4), 383-397.
Hahn, J., Hausman, J. \& Kuersteiner, G. (2004) Estimation with Weak Instruments: Accuracy of HigherOrder Bias and MSE Approximations. Econometrics Journal, 7 (1), 272-306.

Harrison, L.E. (1985). Underdevelopment Is a State of Mind: The Latin American Case. Lanham, MD: Madison Books.

Herrera, J., Razafindrakoto, M., \& Roubaud, F. (2007). Governance, Democracy and Poverty Reduction: Lessons drawn from household surveys in subSaharan Africa and Latin America. International Statistical Review, 75 (1), 70-95.

Hunt, J. (2004). Trust and bribery: The role of quid pro quo and the link with crime (Working Paper No. 10510). National Bureau of Economic Research.

Hunt, J. \& Laszlo, S. (2005). Bribery: Who pays, who refuses, what are the payoffs? (Working Paper No. 11635). National Bureau of Economic Research.

Johnston, M. (2000, August 2). The New Corruption Rankings: Implications for Analysis and Reform. Retrieved from http://departments.colgate.edu/polisci/ papers/mjohnston/originals/JohnstonIPSA2000.pdf

Kowalewski, O. (2012). Corporate Governance and Pension Fund Performance. Contemporary Economics, 6 (1), 14-44.

Lee, L. (1992). Amemiyass Generalized Least Squares and Tests of Overidenfication in Simultaneous Equation Models with Qualitative or Limited Dependent Variables. Econometric Reviews, 11 (3), 319-328.

Murray, M. P. (2006) Avoiding Invalid Instruments and Coping with Weak Instruments. Journal of Economic Perspectives, 20 (4), 111-132.

Mocan, N. (2008). What determines corruption? International evidence from micro data. Economic Inquiry, 46 (4), 493-510.

Mocan, N. H. \& Rees, D. (2005) Economic Conditions, Deterrence, and Juvenile Crime: Evidence from Micro Data. American Law and Economics Review 7 (2), 319-349.

Shaw, P. (2009). The determinants of educational corruption: The case of Ukraine. University of Hull. Retrieved from http://www.hull.ac.uk/php/ecskrb/GDP2009/Shaw2_Ukrain_GDP2009.pdf

Smith, R. J., \& Blundell, R. W. (1986). An exogeneity test for a simultaneous equation Tobit model with an application to labor supply. Econometrica, 54 (4), 679-686 
Svensson, J. (2003). Who Must Pay Bribes and How Much? Evidence from a Cross Section of Firms. The Quarterly Journal of Economics, 118 (1), 207-230.

Swamy, A., Knack, S., Lee, Y., \& Azfar, O. (2001). Gender and corruption. Journal of Development Economics, 64 (1), 25-55.

Torgler, B., and Valev, N. T. (2006). Corruption and age. Journal of Bioeconomics, 8 (2), 133-145.

Transparency International Bangladesh (2008). National Household Survey 2007 on Corruption in Bangladesh. TIB, Dhaka. Retrieved fromhttp:// www.ti-bangladesh.org/research/HHSurvey07full180608.pdf

Wooldridge, J. M. (2002). Econometric Analysis of Cross Section and Panel Data (2nd Edition). Cambridge, MA: The MIT Press.

\section{Endnotes}

1 An upazila is an administrative unit in Bangladesh that is below the district level but above the village level.

2 The survey focused on rice farming because it is the country's major crop, with the highest area coverage (75\% of the total cropped area and over $80 \%$ of the total irrigated area); it accounts for $50 \%$ of the agricultural GDP and one-sixth of the national income (Bangladesh Rice Research Institute [BRRI], 2012).

3 The survey selected extensive rice producing areas because agricultural extension services (e.g., training, demonstration plots and advisory services, etc.) are greater in these areas. Furthermore, a relatively high share of the agricultural subsidy goes to these areas.

4 We performed the Amemiya-Lee-Newey overidentification test for the validity of the used instruments (Lee, 1992). The test statistic is insignificant, which argues for the validity of the instruments. The Smith-Blundell test was performed to test the endogeneity of the income variable (Smith and Blundell, 1986). The insignificant test statistic implies that the variable is exogenous, and hence the IV approach is not necessary. The Wald test of exogeneity test correlation between the error term in the structural equation and the reduced-form equation for the endogenous variable (Wooldridge, 2002). Failure to reject the null hypothesis means that the error terms in the structural equation and instrumented regression are uncorrelated, and therefore following the IV approach is not necessary.

\section{Acknowledgements}

The authors gratefully acknowledge the financial support provided by the German Academic Exchange Service (DAAD). The authors are very grateful to the two anonymous referees for their helpful comments on an earlier version of the paper. All errors remain ours. 
